DOI https://doi.org/10.30525/978-9934-26-110-7-2

\title{
РЕПРЕЗЕНТАЦІЯ БЕЗОСОБОВИХ РЕЧЕНЬ У ПОВІСТІ АНАТОЛІЯ ДІМАРОВА «ГАПОЧКА»
}

\author{
Гандзюк О. М. \\ кандидат філологічних наук, \\ доиент кафедри украӥнської мови \\ Волинський національний університет імені Лесі Украйнки \\ м. Луиькк, Украӥна
}

У синтаксичній структурі української мови речення з одним головним членом займають особливе місце. Ці синтаксичні одиниці «специфічні за будовою, значною мірою і за змістом та виконуваною синтаксичною функцією» $[1$, с. 130$]$.

Безособові конструкції «становлять найбільш поширений тип речень односкладної будови» [2, с. 244]. Вони усталено вживаються в мові.

Ці конструкції дуже поширені у творах художньої літератури. Аналіз безособових односкладних речень проводимо на матеріалі повісті Анатолія Дімарова «Гапочка» (К.: Радянський письменник, 1987, C. 82-158).

Зокрема, їх вживають на позначення явищ природного всеохоплюючого характеру: Гапочка повернувся в село, коли зовсім стемніло (c. 146); Тепер, коли зсутеніло, він подумав : «Пора»! (с. 91); Німиі, напевнее, вистежсили їх, коли вони добиралися до передової, але ще не стемніло, а фашисти не хотіли йти на невиправданий риск, тож залягли і стали чекати, коли командири вертатимуться (с. 129); Світало (с. 144); Леся, мов відчуваючи що в них нелад, пішла додому, в Софоньки розболілася голова, $i$ вона лягла в постіль, ще й не смеркалося (с. 155).

У тексті функціонують й особові дієслова, вжиті в безособовому значенні: Глянув донизу, на галіфе: роздерте вище коліна - шматонуло осколком? (с. 133); Од комбата пахло фронтовими ста граммами (c. 133); Тут пахло супом, смаженим м'ясом $i$ Софонькою (с. 86); В обличчя йому так і вдарило сирістю (с. 125); . ...там уже догорало в nечi... (c. 143).

Тут присутні й безособові речення «з безособовим дієсловом у функції головного члена, які містять повідомлення про переживання, настрої, почуття людини, виникнення і перебіг яких не залежать від іiі 
волі» [1, с. 147]: ...Гапочку ажс нудило... (с. 86); Тут Гапочку кидало в жар... (с. 155); Йому аж в очах запекло...[1, с. 114].

У тканині тору наявні дієслова, які показують незалежні від особи процеси: I рвонуло, і вибухнуло, й обкидало тванню... (с. 127); Він рвонувся, покотивсь по землі, щзосили ударив когось, аж хруснуло, ухопив, крутонув, вивертаючи руку, щчо тягнулась до рота, знов зірвався на ноги, наосліп б'ючи і одразу ж попереду, од темної постаті, гостро спалахнуло, тріснуло, обпекло Гапочиі шию (с. 129); Я зіткнувся 3 Гапочкою на пероні $і$ пройшов уже був мимо, не впізнавщи одразу, а потім мене наче штовхнуло в груди: та це ж Гапочка! (с. 157); Перепало вам! - поспівчував кореспондент (с. 134).

Іншу групу складають безособові речення 3 семантикою бажання: Гапочйі захотілося дістати ту воду, відчути ї̈ смак на вустах, та чомусь не наважувався розбивати настояну й добру пітьму, що наповнювала колодязь по вінця, він тільки погладив цямрину, доторкнувсь до відра: все було йому до щему знайоме, все мов чекало на нього всі оці роки, чекало мовчазно й терпляче, - Гапочка щасливо зітхнув і пішов до воріт (с. 144); Панасові ж Юхимовичу зараз иъього найменше хотілось (с. 82-83); Гапочка із жалем дивився на Зайчика: до щеему в сериі хотілося, щеб очей «хвостик» хоч трохи пожив (с. 126).

Ще один вид безособових дієслів наділений семантикою почуттів людини: Пес підставляв чорну голову під Сашкову руку, очі ж винувато відводив од Гапочки: щуо я маю робити, коли йому ие подобається говорив увесь його вигляд ? (с. 156); Цього разу не побачив жодної зірки, отже, німиі не зможуть бомбити, - Гапочиці аж на душі розпогодилося, і він, повеселілий ураз, піднявся сходинками, пішов до прибулих (с. 125); Було аж не по собі: чи то від згадки про непродані яблука, чи од невтішних думок про сердиту на нього дружину (с. 112); Гапочиі теж було не по собі від иієї незвичної тиші... (с. 128)

Безособові речення можуть містити у своєму складі дієслова зі значенням успіху/неуспіху: Відрізок часу на війні величезний, майже вічність, бо значна частина тих, хто воював поруч із Гапочкою, у вічність $і$ пішла, а йому щастило, його навіть не дряпонуло, наче оберігала закоханість в юну дружину: ніс ї̈ у собі з дня у день, через усі бої та походи, і німо не могло ї̈ пригасити (с. 104); Соня не раз казала, що Юрченки хоч трохи й «3 привітом», але люди загалом хоромі, $і$ ӥм повезло на сусідів (с. 122).

У тексті наявні речення, в яких йдеться про процес сприймання людиною якоїсь реалії: Панас Юхимович аж морщиться болісно: йому 
тепер здасться, щуо Зайчик пожив би довще, коли б він його відправив y взвод (с. 126).

У повісті репрезентовано безособові форми 3 предикативним словом нема (немає): - У мене немає батьків, - крізь сльози сказала дружина (с. 105); - Немає Кіндратівни... (с. 111); Ні справа, ні зліва ще немає сусідів... (с. 111); -У мене тут роддому немає (с. 124); - Київської міліиії на тебе немає! (с. 145); ...йому кінияя-краю немає (с. 145).

Безособовими в повісті $є$ й конструкції 3 компонентом нема, не було: ... але фото не було $i$ в книжках (с.124); У вагоні було повно різкого, неприємного світла $i$ веселий гомін якихось молодиків з гітарою...(с. 156).

У тексті твору $є$ форми, які сигналізують про наявність чи відсутність певних реалій: Софонька після цього остаточно переконалась, щио сусідам бракує десятої клепки (с. 115); Ніколи ще не було за їхнім столом так жваво та весело, наповнена дитячими голосами, кімната аж посвітліла, дихнула тим милим затишком, якого - лише зараз відчув болісно Гапочка - так їм бракувало (с. 153);

Сюди належать i форми з предикативними прислівниками: Йому стало так незручно, щзо він ступив був услід, та знову загадав про дружину (с. 83); Та й Софоньці було б веселіше, не так, може, нервувала ... (с. 153); Тут було не так порожньо: вештався люд, котились машини (с. 83); В чайній було гамірно, тісно, чадно (с. 85); У вагоні було порожнььо, ще жодного разу не повертався Гапочка так рано додому (с. 112); Голо, порожньо, сумно стало в саду... (с. 114); Довкола було тихо і мертво, лише на передовій, за якихось двісті метрів од нього затріщуали автоматні й гвинтівочні постріли, довгою нерівною прошвою обізвався кулемет (с. 130); Йому завжди аж незручно було за свій апетит, але щзо мав робити? (с. 87); - Та мовби не чутно... (с. 129); Соня тулиться все щүільніше й щзільніше, бо ж надворі вже холодно... (с. 99); ... матері твойй буде приємно? (с. 118); ...йому стало аж легше (с. 133); ...на душі в нього ставало тепло й затишно (с. 137); - ...Нелегко було ӥй з дитиною (с. 140)

Ще одним показником безособового значення $\epsilon$ наявність форм на но-, то-: Старенька ж усміхнулася приязно, ще й головою покивала: Одчинено... Одчинено... (с. 83); - Організуй все, як положено! (с. 98); Нате, пишіть, щчо положено! (с. 100); I після того, як було зламано кілька вудок, $і$ кілька матерів перестріли Юрченка на вулиці з останнім, сто п'ятим, як на той час у газетах писалося, попередженням, придумав сусід для своӥх підшефних іншу забаву: збирати по лісах, по лугах залишки зброї, шуо посіяла густо війна (с. 120); I під кожним отим 
експонатом - акуратна табличка: знайдено там-то $i$ там-то... (c. 120); ...а перед тим було надруковано великий, на три колонки, нарис у республіканській газеті... (с. 138).

Деякі безособові речення можна вважати своєрідними відповідниками двоскладних структур: - A стоятиме, куди йому дітися? (с. 156) - А стоятиме, куди він дінеться?; Не сиділося й політрукові, і вони тепер уже втрьох, разом із Зайчиком, рушили на передову (с. 128) - Не сидів і політрук.

У повісті А. Дімарова «Гапочка» репрезентовано безособові речення. Серед них переважають структури з предикативними прислівниками.

\title{
Література:
}

1. Дудик П.С., Прокопчук Л.В. Синтаксис української мови: підручник. К.: Видавничий центр «Академія», 2010. 384 с.

2. Сучасна українська літературна мова: Синтаксис / за заг. ред. І. К. Білодіда. К. : Наук. думка, 1972. 515 с.

DOI https://doi.org/10.30525/978-9934-26-110-7-3

\section{КОНЦЕПТ «ОБ' ЄКТИВНА РЕАЛЬНІСТЬ» ЯК ХАРАКТЕРИСТИКА КОНЦЕПТОСФЕРИ «ЛЮДИНА»}

\author{
Дишлева Г. В. \\ викладач кафедри іноземних мов за фахом \\ Національний авіаційний університет \\ м. Київ, Україна
}

Людина живе в об’єктивній реальності, яку вона протягом усього існування наполегливо й ненастанно прагне пізнати, намагається у міру власних можливостей змінити іiі, модифікувати певним чином, пристосувати до своїх потреб. Філософський енциклопедичний словник [2002] так визначає це поняття: «Об'єктивна реальність (природа, матерія) - це буття, існування і властивості якого не залежать від того, чи сприймає (мислить) його якийсь суб'єкт, чи ні. Об'єктивна реальність у цьому сенсі - те, що існує «поза свідомістю» і «незалежно від свідомості» суб'єкта» [3, с. 446 ]. Необхідність введення цієї філософської категорії була зумовлена здійсненим Декартом поділом світу на внутрішній (світ «Я» - суб'єктивної реальності, феноменів, мислення, свідомості) і зовнішній (світ «не Я»- чуттєвих, тілесних 